\title{
Climate Change and Forests
}

\section{Emerging Policy and Market Opportunities}

Charlotte Streck, Robert O'Sullivan, Toby Janson-Smith and Richard Tarasofsky (Editors), 2008. ISBN 978-0-8157-8192-9. Brookings Institute Press, Washington, D.C. US \$69.95 + shipping. Contact: ssoldavin@brookings.edu

limate change is one of the most significant challenges of our time. To date, international efforts have focused primarily on the industrial and energy sectors, overlooking a crucial piece of this intricate puzzle. The forest and land-use sector remains one of the most significant untapped opportunities for carbon mitigation. Climate Change and Forests provides a fresh approach by explaining the links between climate change and agriculture and forestry, highlighting the unexplored potential of this sector within emerging climate policy frameworks and carbon markets.

This timely work brings forests, the world's most important terrestrial storehouses of carbon, to the forefront. It focuses on the key topic of assigning value to emission reduction and removals by creating tradeable carbon credits, a developed and promising strategy. With the implementation of such a system, even the world's poorest people can participate and benefit from the global carbon market. In addition, an international team of experts discuss sequestration rights in Chile, carbon offset programs in Australia and New Zealand, and the emerging policy incentives at all levels of the U.S. government.

Climate Change and Forests will serve as a practical reference manual for anyone concerned about climate change policy, including the negotiators working to define an enduring framework for addressing global climate change.

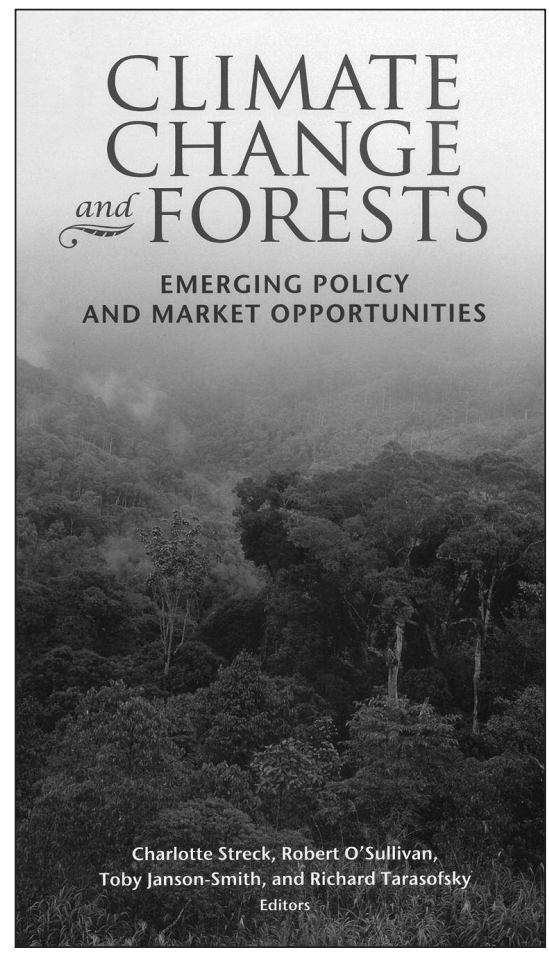

\section{Awful Splendour - A Fire History of Canada}

Stephen J. Pyne 2007. ISBN 978-0-7748 University of British Columbia Press $\$ 34.95$ (cloth) + shipping. See: ubcpress.ca

tephen Pyne has done it againanother sweeping historical epic about forests, people and fire-this time set in Canada.

Forest fires always provide spectacular and colourful stories that feature prominently on national TV news in the annual cycle of natural disasters, such as blizzards, avalanches, ice storms, tornadoes and hurricanes, floods, washouts and droughts.

Alone among these phenomena, forest fire is considered an event that humans should be able to prevent or control. Some also suggest that their seeming increase is related to climate change. But fire has been a natural part of forest and grassland ecosystems ever since the retreat of the great glaciers about 10000 to 15000 years ago. It was when people showed up soon after that humans and fire began their long history of collaboration and conflict. This book is a magnificent account of the sweep of fire in Canada and its interaction with people.

This book tells an engrossing story about forests and fire in Canada from

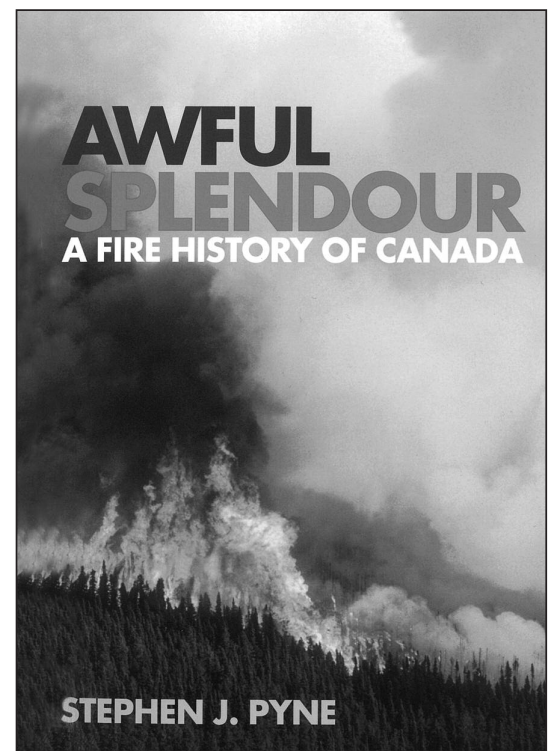


the time of the first post-glacial plants to the present. Steve Pyne spent over five years gathering information, speaking to people, organizing his thoughts and writing. He took as his theme: Reconciling rhythms of the boreal environment with the dynamics of social institutions. It is both a natural history and a historical geography

Stephen J. Pyne is a world-renowned ecologist and historian whose research interests focus on how people and nature interact. Presently Regents Professor at Arizona State University at Tempe, he teaches and writes with a special enthusiasm for the history, ecology, and management of fire. Author of twenty books, Awful Splendour is his most recent publication, the seventh in his series Cycle of Fire.

Pyne logically divided the book into three time periods. The Torch describes the natural role of fire in the forest and life of the first people. The Axe is the frontier development from the fur trade through early settlement and timber trade. The Engine takes the story from the steam engine and machines to the present.

In "Torch," Pyne describes how climate and fire interact. He then reviews the ecological and historic role of fire across Canada, first at the northern fringe of tundra between ice and forest, then the Great Plains Prairies and Great Lakes regions, concluding with the Canadian "bookends" of the mountains of the east and west coasts. Included in this is a review of Aboriginal fire applied to landscapes to influence ecosystem conditions, essential to sustain life in these northern Canadian latitudes.

The "Axe" describes the influence of the steel axe as wielded by Europeans, first cutting trees as an adjunct to fishing, followed by clearing for agriculture and settlement, then logging for the timber trade and domestic use. The axe and those who wielded it created new fuel-beds of slash as well as generating sparks to ignite them and other forest fuels, which vastly increased the amount and timing of fires. This, in turn, led to thoughts about how to contain them and how the conservation movement grew.

The "Engine" represents the present period that began with the "industrial fire" of the steam engine and successive development of internal combustion and other machines-industrial fire "of such immense power that it forced a tectonic shift of fire throughout the planet.' In this book Pyne tells the separate histories of the provincial and federal fire services. He also relates them to important national historic events. He adroitly alternates the separate histories with national historical themes and examples, all engrossingly told in a way that holds reader interest.

Pyne skillfully describes the essence of the perennial Canadian quandary of trying to achieve goals in the "national interest" despite the complexities of provincial-federal-industry-public interests and the ongoing struggle to try to find a working balance among them with respect to authority, responsibility and, especially, who pays. For example, summarizing the attempts in 1924 to reach consensus on ways to cooperate in fire control, he observed:

"Ottawa wanted the provinces to practice conservation, for it was of national interest in two vital industries, logging and settlement. But it would not (or could not) pay for such practices. The provinces wanted the Dominion to pay, but would not (or could not) yield to Ottawa any substantial or even symbolic control over what they might do." (Forest Fire Conference 1924, Pyne p. 179)

Included are stories about the pioneering fire behaviour researchers Jim Wright and Herb Beall. He paid tribute to Charlie Van Wagner, who he felt personified a Canadian spirit in leading and collaboratively developing the unique Canadian Forest Fire Danger Rating System independently of and in competition with the U.S. approach:

Another highlight is a well-told story about fire management in Parks Canada and how fire was enabled to be reintroduced to the ecosystembrought about by some dedicated individuals, especially Cliff White and Ian Pengelly, who enlisted Parks Canada and public support through their wellthought-out plans-actions that opened the door to a lot of new thinking about the applied use of fire in land management.

Pyne's conclusions are refreshing, thought-provoking and challenging. Some are reminiscent of Robert Burns' often quoted: "O wad some Power gie us To see oursels as ithers see us!"

He capably links the dynamics of fire in the ecosystem with people, places and events. It will appeal most to those with interests in ecology, ecosystem dynamics, resource management, history, policy, environment and climate change.

Reviewed by: Marty Alexander Associate Editor, Wildland Fire Science and Management The Forestry Chronicle

Editor's Note The CIF/IFC national office receives several excellent publications throughout the year. These will be announced to our readers. Reviewers are needed. We have only one copy of any publication and it is yours to keep or donate to a forestry faculty or college of your choice. If you are interested in reviewing a book, please contact the national office. E-mail: admin@cif-ifc.org. 


\section{Finer Than Hair on a Frog - More Varns About Loggers and the like}

Brent A. Connelly, 2007. ISBN 978-1-897113-89-9 General Store Publishing House, Renfrew, Ontario. \$19.95 + shipping. Contact: alisonroesler@grph.com

$\mathrm{t}$ is very much an understatement to say that Brent Connelly is a great storyteller. Like his first book Holy Old Whistlin' - Yarns about Algonquin Park Loggers, this second offering is both entertaining and interesting, and leaves you with that certain ineffable warm feeling. Although his colloquial writing style is a little different, for me it is somewhat reminiscent of acclaimed British veterinarian and author James Herriot in the way the story is told, with the descriptions of all kinds of unique and very real people, their personalities and foibles; and their adventures and often misadventures.

In Finer Than Hair on a Frog, Connelly not only spins some great yarns about forestry folk, he does a real favour and tangible service for the forest sector in general. The book both indirectly and directly describes and extols many aspects, intricacies and realities of forest operations, as well as the positive virtues and ethics of the people involved therein: hard-working men and women who tend not to take themselves too seriously and can always have a laugh at their own expense. But most importantly these people invariably love the bush and want to do a good job in every respect. The book generally and simply exudes these kinds of sentiments about people, most often not in any deliberate way but just as an observation from a person who obviously likes people and easily sees the good in everyone.

Geographically, Finer Than Hair on a Frog ventures to Algoma country, specifically to Lake Superior Provincial Park, where at one time timber harvesting was permitted, and of course takes us back to Algonquin Park country where he spent most of his career. Having worked as a park naturalist in Lake Superior Park and canoeing in both Algonquin and Superior, it is interesting to get a completely different take on these special places that have such wonderful natural and human history. And one does not necessarily require any direct familiarity with these locations to enjoy the book. Connelly justifiably has a lot to be proud of in his writing about this much misunderstood and unfairly maligned aspect of the Park. Finer Than

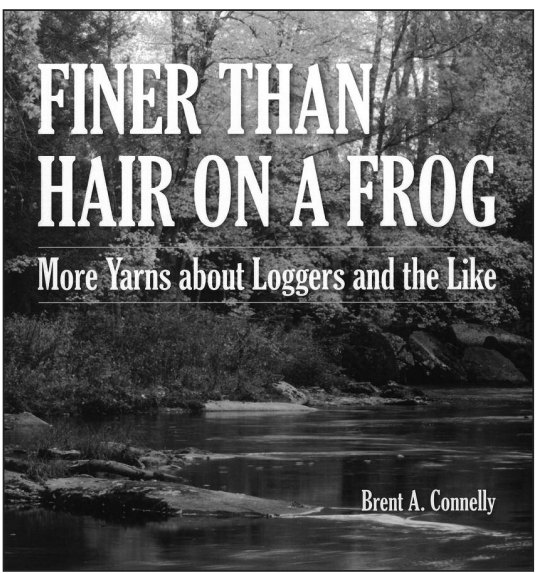

Hair on a Frog is not meant to kindle some kind of green debate, although I could certainly cite some passages that would help me in such a situation.

I recommend that a relaxing perusal of this pleasant little gem of a book will without a doubt have you feeling finer than hair on a frog!

Reviewed by John Pineau

\section{A REMINDER ...}

Articles from Sections, Universities and Colleges, and brief articles (800 words or less) on national and international forestry have a deadline of the first week of the month preceding the intended issue, i.e., for the November/December Chronicle, articles are required by the first week of October. Articles may include news of past or upcoming events, specific news items on members' accomplishments (awards, books published, etc.).

\section{High-resolution photographs are welcomed.}

Information on upcoming meetings, conferences, training courses and similar items that may be of national or regional interest can be listed throughout the Chronicle. 


\section{Viure les changements climatiques - Réagir pour l'avenir}

Claude Villeneuve et François Richard. 2007. ISBN 978-2-89544-117-5.

Éditions Multimondes, Québec. www.multim.com

N ous avons tenté de clarifier le sujet sans sacrifier la rigueur qui est nécessaire pour bien saisir la portée des travaux qui sont relatés » (p.18) Voilà ce que nous annoncent, d'entrée de jeu, Villeneuve et Richard dans leur ouvrage intitulé Vivre les changements climatiques - Réagir pour lavenir, paru aux éditions MultiMondes. Le moins qu'on puisse dire, c'est qu'ils ont atteint cet objectif.

En effet, lédition 2007 de Vivre les changements climatiques, la troisième en son genre, a été soigneusement révisée afin d'incorporer l'information et les données les plus récentes. Les auteurs y font abondamment référence au dernier rapport du Groupe intergouvernemental d'experts sur lévolution du climat, notamment.

Vivre les changements climatiques traite de chimie et de physique, de climatologie, de biologie, de politique et de culture, tout en présentant au lecteur des façons simples et concrètes de contribuer à la mitigation des changements climatiques. Les auteurs utilisent un langage coloré et imagé pour présenter des idées parfois complexes, soutenues par des connaissances solides et une abondante littérature.

Prédire oui, mais agir aussi : Parmi les lecteurs, les professionnels de domaine des sciences forestières et biologiques ne seront pas étrangers aux propos figurant au chapitre six, intitulé Top Modèles. Les auteurs y abordent les progrès récemment accomplis dans le domaine de la modélisation, tout en reconnaissant les limites, dans la vie de tous les jours, de l'utilisation de tels outils et de leurs prédictions: « les avancées (dans le domaine de la modélisation) ne seront utiles que si les prévisions régionales réussissent à traduire des résultats scientifiques en décisions et en actions de la part des décideurs et des populations concernées. » (p.130).

Les forêts : puits ou source de carbone? Ces mêmes modèles, soulignent Villeneuve et Richard, " arrivent à des conclusions différentes quant au rôle des forêts comme puits de carbone. » (p.158). Les auteurs affirment néanmoins qu' " en matière de gaz à effet de serres, il est sain de récolter les forêts, car un arbre jeune pousse plus vite et donc fixe plus de $\mathrm{CO}_{2}$ qu'un arbre sénescent. » (p.212). Voilà un argument de force sur lequel pourront s'appuyer les forestiers afin de promouvoir l'aménagement durable comme moyen de réduire les émissions de carbone. Les auteurs rappellent toutefois que la remise en production des aires de récolte est une condition sine qua none pour que les forêts aménagées soient considérées comme puits de carbone. Les auteurs abordent en détails les mécanismes de stockage du carbone dans la matière ligneuse à la section "fixer le carbone dans les arbres" (p.368).

Villeneuve et Richard présentent également les principes sur lesquels se base le calcul du bilan de carbone et des crédits qui y sont associés. Le bilan de carbone des forêts, selon les auteurs, «deviendra un enjeu important dans le cadre du marché des droits démission.» (p.401). Ils ajoutent que des données relatives au cycle de vie complet des produits du bois seront nécessaires afin de déterminer dans quelle proportion le volume de bois récolté sera admissible pour la reconnaissance des crédits.

Transformer la biomasse en énergie : Lutilisation de la biomasse pour produire de l'énergie constitue l'un des moyens que préconisent Villeneuve et

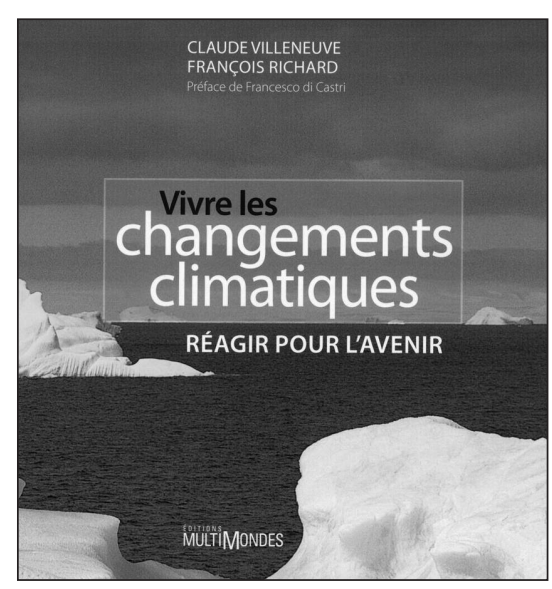

Richard pour favoriser la réduction des émissions de gaz à effet de serres. Bien que la conversion du maïs en éthanolune pratique courante aujourd'huifasse partie des avenues possibles, les auteurs affirment qu'il ne s'agit là que d'une première étape et que les véritables progrès en matière de bioénergie surviendront avec le développement de technologies capables de produire du carburant à partir de cellules ligneuses. Voilà peut-être une voie sur laquelle l'industrie forestière pourrait s'engager afin de diversifier sa production et de se renouveler?

Sujet chaud au palmarès des lectures d'été : Avec l'arrivée du printemps et l'annonce des premières alertes au smog (déjà?), les lecteurs avertis se plongeront avec grand intérêt dans la lecture de louvrage incontournable que constitue Vivre les changements climatiques - Réagir pour lavenir dans le dossier des changements climatiques.

Aude Fournier, R.P.F.

Programme international de partenariats en foresterie Ressources naturelles Canada 